\title{
EMPOWERING RURAL-REMOTE DOCTORS THROUGH DISTANCE CME: A LITERATURE STUDY
}

\author{
Kristian Wongso Giamto \\ General Practitioner, Chasan Busoirie Public Hospital of Ternate \\ North Maluku
}

\section{ABSTRACT}

Background: Doctors in rural and remote areas in eastern Indonesia, particularly North Maluku (northern part of the Moluccas Islands), are burdened with difficulties in their daily practice due to shortage of radiology or laboratory devices and other medical specialties. Travel distance and cost sometimes made referral to a better health facility impossible. They also have limited accessibility to live Continuing Medical Education (CME), due to relatively high travel cost and limited health professionals remaining while they are absent. However, in this challenging situation, they still obliged to deliver the most optimal medical services possible. In some ways, such setting is more challenging than working as a doctor in urban area.

Method: This paper derived its data from scientific journal publications, newspaper and also direct interview. Results: Online CME may be a very promising method to empower doctors in rural and remote settings. More awareness to the significance of CME, especially, to rural and remote doctors is needed. Further advocacy and collaboration among stakeholders are needed to support this idea, which is relevant not only to rural and remote doctors in North Maluku, but also in other eastern parts, and perhaps in other remote areas in entire Indonesia.

Conclusion: Online CME, as proven by evidence-based findings, will reduce professional isolation and equip them cognitively. This empowerment will ultimately benefit patients and, indirectly, other sectors as well.

Keywords: remote and rural doctors, distance CME, distance learning, North Maluku, eastern Indonesia

\section{ABSTRAK}

Latar Belakang: Dokter-dokter yang berada di daerah pelosok dan terpencil di Indonesia timur, dalam hal ini Maluku Utara, menghadapi tantangan-tantangan tersendiri dalam menjalankan praktik klinis sehari-hari. Hal ini diakibatkan kurangnya layanan radiologi atau laboratorium dan layanan spesialistik medis lainnya. Jarak tempuh dan biaya tinggi kadang menyebabkan proses perujukan menjadi tidak memungkinkan. Keterbatasan akses terhadap Pendidikan Kedokteran Berkelanjutan (PKB) yang diadakan melalui seminar, terutama diakibatkan oleh biaya perjalanan yang relatif tinggi dan kelangkaan tenaga pengganti saat mereka sedang tidak berada di tempat. Namun, dalam kondisi yang sarat keterbatasan ini, sebagai dokter, mereka tetap berkewajiban memberikan pelayanan medis paling optimal. Dalam beberapa hal, dapat dikatakan bahwa keadaan seperti ini lebih menantang dibanding berpraktik di daerah perkotaan.

Metode: Artikel ini menggunakan data-data yang bersumber dari publikasi-publikasi jurnal ilmiah, koran dan juga wawancara langsung.

Hasil: PKB online dapat merupakan salah satu cara yang sangat menjanjikan dalam memberdayakan dokter di daerah pelosok dan terpencil. Kesadaran yang lebih terhadap signifikansi PKB, khususnya untuk dokter di daerah pelosok dan pedalaman sangatlah diperlukan. Advokasi dan kolaborasi antar pemangku kebijakan dibutuhkan untuk mendukung ide, yang relevan bukan hanya untuk dokter di daerah pelosok dan pedalaman yang ada di Maluku Utara, namun juga di bagian Indonesia timur lainnya, dan mungkin di seluruh Indonesia.

korespondensi: kristianyan@gmail.com 
Kesimpulan: PKB online, sebagaimana dinyatakan oleh temuan-temuan yang berbasis bukti, akan mengurangi isolasi profesional dan memperlengkapi dokter di daerah pelosok dan pedalaman secara kognitif. Pemberdayaan ini akan sangat menguntungkan pasien dan, secara tidak langsung, kepada sektor-sektor lain.

Kata kunci: dokter pedalaman dan pelosok, PKB jarak jauh, pembelajaran jarak jauh, Maluku Utara, Indonesia timur

\section{INTRODUCTION}

"A young man, 25 years old, was admitted to the hospital after a motorcycle accident two hours previously. He was unconscious for 10 minutes, had five episodes of projectile vomiting and appeared lethargic. Upon inspection, a large bruise was found in his abdomen. No CT scan and ultrasound available in the hospital. The nearest hospital with a better facility can only be reached in 5-6 hours time and the family could not afford the referral cost."

This is just an illustration of one of many complicated cases routinely encountered in North Maluku. Similar cases are also found in other rural and remote areas in other parts of Indonesia.

Indonesia, the largest archipelago in the world, has more than 17,000 islands. This maritime territory with unequal population distribution leads to an emerging health problem: unequal distribution of health care services. Despite the extensive area it covered, eastern Indonesia is less populated compared to other parts of Indonesia, such that this problem is much more visible.

In North Maluku (NM), especially in the great Halmahera Island, we can not rely on a radiological imaging. Other medical specialists are unavailable in some areas. Problems in referring patients are also very dilemmatic.

This paper studies why and how online Continuing Medical Education (CME) is very potential in empowering general practitioners in this tough setting, so that delivery of the most attainable quality of service is possible, for the benefit of patients.

\section{METHOD}

Data in this research was primarily derived from MEDLINE, by entering keywords "rural doctors", "remote doctors", "online CME", "e-learning CME", and "CME internet". Search results were restricted to relevant publications within the timeframe of the year 2000 until present. More data was also obtained from other sources (newspapers and publications of governmental and professional organizations) as relevant to this writing.

Direct interviews were also conducted towards mobile provider network provider officers and fixedline provider in Ternate to obtain information of internet coverage area in NM.

\section{RESULTS AND DISCUSSION}

\section{Definitions}

American Medical Association and the Council on Medical Education define CME as "educational activities which serve to maintain, develop, or increase the knowledge, skills, and professional performance and relationships that a doctor uses to provide services for patients, the public, or the profession. The content of CME is the body of knowledge and skills generally recognized and accepted by the profession as within the basic medical sciences, the discipline of clinical medicine and the provision of health care to the public." ${ }^{1}$

IDI (Ikatan Dokter Indonesia, Indonesian Physician Association) defines CPD (Continuing Professional Development) as a systematic oversight to improve physician's knowledge, skill, and attitude for good conduct of their profession. ${ }^{2}$

\section{Distance learning}

Simonson defines distance education as institutionbased formal education where the learning group is separated, and interactive telecommunications system are used to connect learners, resources, and instructors. ${ }^{3}$ 


\section{Rurality and Remoteness}

This paper understands the concept of rurality as Health Systems Trust (HST) and defines "rural health care" as "the provision of health services to areas outside of metropolitan centres where there is no ready access to medical specialists, intensive and/ or high technology care, and where resources, both human and material, are lacking. This service may be provided within hospitals, health centres, clinics, or independent practices. It is best provided by a team of health care workers and is based on the principles of primary health care." 4

Definition of remoteness in the medical context is based from Smith et al (2008), "practice as locations that are geographically, professionally, and personally isolated with limited sophistication of medical and logistic support, limited access to peers, or in extreme climatic, political or cross-cultural environments." 5
As the overlapping definition of 'remote medical practice' and 'rural health care', this paper will equalize and use them interchangeably.

\section{North Maluku}

North Maluku refers to an province in northern portion of Maluku (Moluccas) Islands, Indonesia, which consists of 805 islands, with only 82 of them are inhabited (10,2\%). In 2012, official government data shows that NM were inhabited by $1,088,673$ people. ${ }^{6}$

\section{CME and Medical Doctors in NM}

Most CME is held in the western parts of Indonesia, and less is done in the eastern part, assumes to be in accordance to the distribution of medical schools and institutions which are predominantly located in western Indonesia (e.g. Jakarta, Surabaya, etc). There are only two medical school out of 72 in Indonesia, which locate in eastern Indonesia. ${ }^{8}$

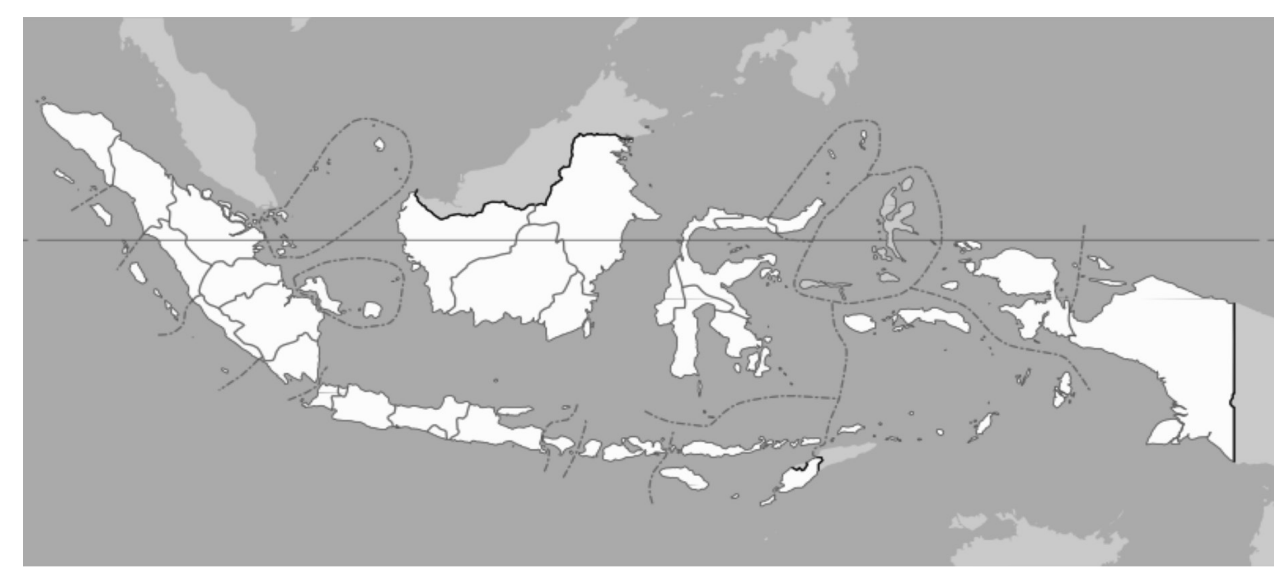

Picture 1. NM Territory (green) ${ }^{7}$

Ministry of Health (2012) data reveals that there are 39 medical specialists, 174 general practitioners and 36 dentists establishing medical practice in NM. ${ }^{9}$ According to Indonesia's Health Map 2012 eastern Indonesia is almost always classified as having the largest burden index of disease (red color) compared to other zones, in cases of neonatal death, infant death, pneumonia, annual parasite incidence malaria, and new cases of leprosy. ${ }^{10}$
There are at least two main reasons why it is often difficult to attend live CME held outside NM:

1. Travel cost

To attend a medical seminar or workshop in Java (e.g. Jakarta or Surabaya), one must also allocate travel and accommodation cost. Two-way trip from Ternate to Surabaya for one person can cost approximately IDR 2,600,000 to more than IDR 3,400,000 (accommodation fee and cost to reach the nearest airport excluded). They who 
practice in the more eastern part of Indonesia, such as Papua, will have to spend more on travel fee.

Almost always, travel cost is much higher than the cost for the seminar or workshop itself. Generally, seminar registration fee for general practitioners range from IDR 1,000,000 up to IDR $1,500,000$ (price may vary). To date, live $\mathrm{CME}$ applies the same registration fee for doctors regardless of their areas of origin.

2. Limited human resources in NM

This constraint implies that getting off duty for some days to attend live CME will be difficult.

\section{Online CPD: Its Rationale}

\section{Practical Reasons}

Here is why it is extremely important to make CME more accessible to rural and remote doctors:

- To balance shortage or absence of radiology services

To come to a definitive diagnosis, there are three modalities we can use: (1) history taking, (2) physical examination, and (3) radiology (and laboratory) examinations. As laboratory or radiology services are sometimes limited or even completely absent, some diseases are difficult to be diagnosed objectively, like subdural or epidural hematoma which requires a CT Scan or an MRI for a definitive diagnosis. Failure of recognizing the underlying disorder might have catastrophic consequences. When one of three modalities can not be obtained, we have to strengthen the remaining two, which can be done, as evidences prove, effectively through CME.

- General practitioners as "specialists" of all medical field

When medical specialties are often not available and referral can not be done as easily, a general practitioner should act (to a certain level of competence) as medical specialist, such as a pediatrician. In order to achieve this extra knowledge and skill, they need to be equipped with CME.
Professional isolation is a huge burden to rural and remote doctors, as their work could be much more challenging compared to their colleagues in the urban area.

- To retain and recruit rural doctors Evidences show that access to CME is a key factor in recruiting and retaining rural doctors. Access to CME will later positively affect satisfaction and decrease feeling of professional isolation. ${ }^{11}$

- Benefit for other sectors

- professional organization (IDI). By supporting and advocating distance CME, IDI will also fulfill their goal and commitment regarding CPD. ${ }^{2}$

- educational institutions. Educational institutions can learn the practice and may develop the so-called "limited resources medicine" to equip their students.

- the government. Better clinical outcome will positively contribute to the health sector development and reducing health cost burden.

- business sectors. This way of deliverance will open business opportunity for information technology (IT) sectors to get involved in.

Ultimately, the most benefited party from encouragement of online CME is surely patients. Better clinical practice would translate to better clinical outcome and quality of life.

2. CPD Guidelines and Credit Requirement in Indonesia

IDI states that $\mathrm{CPD}$ is an independent learning process of medical doctors, and therefore, its continuity depends on his/her personal motivation. ${ }^{2}$ This statement is totally correct in some perspectives. However, good willingness is often inadequate. Accessibility is a vital factor to consider in the implementation.

For a physician providing direct service to the patients, IDI recommends CPD distribution as: cognitive area $60-70 \%$, psychomotor area 
20-35\%, affective area 10\%, and non-clinical area $10 \% .^{2}$ This signifies the importance of the development of cognitive area in CPD will then mandates cognitive empowerment. However, IDI, which advocates right for doctors to attend CPD, also allows adaptations for rural and remote doctors in fulfilling credit requirements. To personal, this allowance for adaptation should not deny or underestimate the significance of cognitive learning.

3. World Federation of Medical Education (WFME) Recommendations

IDI's guidelines on CPD are based from WFME recommendations. ${ }^{2}$ Some of relevant WFME recommendations ${ }^{12}$ to this paper are listed below:

- Recommendation point 2.5: "CPD must be recognized as an integral part of medical practice reflected in budgets, resource allocations and time planning, and not be subordinate to service demands."

- Recommendation point 6.2: "In order to carry out CPD, doctors must have protected time and opportunities for reflection on practice and for in-depth studies with access to adequate professional literature and opportunities for skills training."

- Recommendation point 6.5: "The medical profession, in collaboration with other stakeholders, must develop systems that encourage and recognize participation in local, national, and international CPD courses, scientific meetings and other formalized activities. Doctors must have opportunities to attend such CPD activities."

- Recommendation point 6.4: "Doctors should have access and be competent to use information and communication technology for self directed learning, for communication with colleagues, information searching, and patient and practice management."
WFME believes that availability and accessibility to CPD must be ensured and also recognizes Internet as a potential way to deliver CPD.

4. Delivering CME through the Net

Advantages: (1) time and location adjustment, (2) increased computer proficiency, (3) more affordable study fee.

Disadvantages: (1) isolation, (2) faculty workload in commenting every single participant, (3) new technology and its over reliance, (4) can not deliver hands-on workshop, (5) requirements of basic computer and internet proficiency. ${ }^{13}$

\section{The Evidences of Online CME}

A study done in 2011 found that being in rural practice and younger in age were significantly associated with the completion of online CME. ${ }^{14}$ This finding is completely understandable. Doctors practicing in rural areas evidently have a greater need for CME. Younger age may reflect computer proficiency. This simple explanation is confirmed by a study conducted in 2009 , which found that senior doctors or doctors with less internet experience might choose in-class $\mathrm{CME}$ rather than an online one. ${ }^{15}$

Participants of CME may prefer in-person presentation to an online presentation. However, mean post-test scores for both methods are quite satisfactory, at more than $80 \%$. Online presentations are found to be more affordable than conventional in-class model of teaching. ${ }^{16}$

A study reported satisfactory results of an online course. Participants from rural health services were compared prior and after the course (using a pre and post-test) and showed statistically significant improvements. ${ }^{17}$ Another study also found that online CME was considered at least as effective as in-person CME in 79\% respondents, and only slightly lower in rating compared to in-class CME. ${ }^{18}$

A study published in 2004, which analyzed data gathered from MEDLINE 1996-2004 and similar journal portals also conclude that 
internet-based $\mathrm{CME}$ are just effective as in-class CME. ${ }^{19} \mathrm{~A}$ meta-analysis of studies conducted in 1990 to 2007 by Cook, et al. also had the same conclusion, ${ }^{20}$ so did a systematic review and meta-analysis of studies from 1990 to $2008 .{ }^{21} \mathrm{An}$ integrative review of relevant studies published by Cobb, et al. identified that barriers to online CME includes technical difficulties and lack of computer proficiency. ${ }^{22}$

\section{Online CME in Indonesia}

In IDI's official website, several online CMEs listed are (1) Journal of the Indonesian Medical Association, (2) CME IDI Online, (3) CME Medicinus Online, and (4) Cermin Dunia Kedokteran (owned by a pharmaceutical company). Some are free and and completion of post-test will be granted credit points. ${ }^{23-26}$

5. Its Feasibility in NM

Two main components in delivering online $\mathrm{CME}$ are course provider portal and internet connections. Internet connections, may be delivered via:

- Wired internet connection

In NM, internet can be accessed anywhere as long as a fixed-line is available.

- Wireless internet connection

Until now, there is only one national mobile provider (from a total of three), which provides $3 \mathrm{G}$ connection in NM. The problem is $3 \mathrm{G}$ coverage is only available in certain areas of NM.

For the purpose of this paper, the writer sent a letter of permission to the main branch of the mobile provider to obtain a map depicting $3 \mathrm{G}$ coverage in NM. Unfortunately, the printed data can not be obtained due to business privacy consideration. Based on a direct interview with an official of the mobile provider, it was known that 3G-covered areas in NM are at least: Ternate, Sofifi, Tobelo, Tidore, Weda, Morotai, Jailolo and Kao (partially).

\section{CONCLUSION}

Doctors in rural and remote areas have the challenge to deliver the best practice possible with very limited resources. Meanwhile, they do not have enough access for live CME. However, due to its undeniable importance, CME must be delivered. If rural doctors can not attend live CME, efforts must be made to ensure accessibility of the CME.

Online CME, as proven by evidence-based findings, will reduce professional isolation and equip them cognitively. This empowerment will ultimately benefit patients and, indirectly, other sectors as well.

\section{SUGGESTION}

Online CME, as supported by evidence-based findings, is expected to empower rural doctors, provided there is ample internet coverage in the area. More advocacy and support, especially from the government and professional organizations are still needed.

Existing online CMEs in Indonesia need to be marketed more properly. More online CMEs are required, with study materials relevant to problems faced by rural and remote doctors.

\section{ACKNOWLEDGEMENTS}

I thank Jovanie C. Espesor, Ph.D (Cand) (Political Science Department, University of Canterbury, New Zealand) for helping me in getting useful readings. I also thank dr. Ferry Valerian Harjito, Sp.PD (Cahya Kawaluyan Hospital, Bandung), a general internist and a personal friend, for his help in editing this manuscript.

\section{DISCLOSURE STATEMENT}

This paper is the revised version of the same paper presented in Indonesian Health Informatics Forum 2015 (October 22-23rd 2015) under the title 'Distance CME as An Alternative to Empower Rural and Remote Doctors in North Maluku', but this paper had not been published to any publishers. 


\section{REFERENCES}

1. Connecticut State Medical Society. Continuing Medical Education [Internet]. Connecticut State Medical Society. 2015 [cited 17 September 2015]. Available from: http://csms.org/cme/

2. Ikatan Dokter Indonesia. Pedoman Pelaksanaan Program Pengembangan Pendidikan Keprofesian Berkelanjutan (Continuing Professional Development). $2^{\text {nd }}$ ed. Jakarta: Ikatan Dokter Indonesia; 2013.

3. Schlosser L, Simonson M, Hudgins T. Distance education. Charlotte, N.C.: IAP -Information Age Pub.; 2010.

4. Hall W. Rural Health Policy Debate [Internet]. Health System Trust. 2003 [cited 17 September 2015]. Available from: http://www.hst.org.za/summarybulletin-7-dhs-lg-discussion-list

5. Smith J, Ayton J, Ross V, Margolis S. Defining remote medical practice. Medical Journal of Australia [Internet]. 2008 [cited 13 September 2015];188(3):159-161. Available from: https://www. mja.com.au/ journal/2008/188/3/defining-remotemedical-practice

6. Kementerian Kesehatan Republik Indonesia. Profil Kesehatan Provinsi Maluku Utara 2012. Jakarta: Kementerian Kesehatan Republik Indonesia; 2013 p. $5-6$.

7. Wikipedia. North Maluku [Internet]. [cited 13 September 2015]. Available from: https://commons. wikimedia.org/wiki/File:IndonesiaNorthMaluku. png

8. Konsil Kedokteran Indonesia. Standar Kompetensi Dokter Indonesia. $2^{\text {nd }}$ ed. Jakarta: Konsil Kedokteran Indonesia; 2012.

9. Kementerian Kesehatan Republik Indonesia. Profil Kesehatan Provinsi Maluku Utara 2012. Jakarta: Kementerian Kesehatan Republik Indonesia; 2013 p. 78.

10. Pusat Data dan Informasi Kementerian Kesehatan. Peta Kesehatan Indonesia Tahun 2012. Jakarta: Pusat Data dan Informasi Kementerian Kesehatan; 2013, p. $12-9$.

11. Curran V, Rourke L, Snow P. A framework for enhancing continuing medical education for rural physicians: A summary of the literature. Med Teach [Internet]. 2010 [cited 19 September 2015];32(11):e501-e508. Available from: http://www. ncbi.nlm.nih. gov/pubmed/21039092
12. World Federation for Medical Education. Continuing Professional Development (CPD) of Medical Doctors: WFME Global Standards for Quality Improvement [Internet]. World Federation for Medical Education. 2003 [cited 16 September 2015]. Available from:http://wfme.org/standards/ $\mathrm{cpd}$ /16-continuing-professional-development-cpd-ofmedical-doctors-english/file

13. Knebel E. The Use and Effect of Distance Education in Healthcare: What Do We Know? [Internet]. Quality Assurance Project. 2001 [cited 19 September 2015]. Available from: https://www.usaidassist.org/ sites/assist/files/distance_education.pdf

14. Butterworth K, Hayes B, Zimmerman M. Remote and rural: do mentors enhance the value of distance learning continuing medical education? Educ Health (Abingdon) [Internet]. 2011 [cited 16 September 2015];24(3):539. Available from: http://www.ncbi. nlm.nih.gov/pubmed/22267349

15. Ruf D, Kriston L, Berner M, Härter M. General practitioners and online continuing medical education - which factors influence its use? Ger Med Sci [Internet]. 2009;24(7):8. Available from: http:// www. ncbi.nlm.nih.gov/pmc/articles/PMC2733536

16. Knapp H, Fletcher M, Taylor A, Chan K, Goetz M. No Clinic Left Behind: Providing Cost-Effective In-Services Via Distance Learning. Journal for Healthcare Quality [Internet]. 2010 [cited 16 September 2015];. Available from: http://www.ncbi. nlm.nih. gov/pubmed/22059939

17. Robinson T, Kelly B, Heathcote S. Outcomes from the trial implementation of a multidisciplinary online learning program in rural mental health emergency care. Educ Health (Abingdon) [Internet]. 2010 [cited 16 September 2015];23(1):351. Available from: http://www.ncbi.nlm.nih.gov/pubmed/20589605

18. Ricci M, Caputo M, Callas P, Gagne M. Telemed $\mathrm{J}$ E Health. The use of telemedicine for delivering continuing medical education in rural communities [Internet]. 2005 [cited 16 September 2015];11(2):1249. Available from:http://www.ncbi.nlm.nih.gov/ pubmed/15857252

19. Wutoh R, Boren S, Balas E. eLearning: a review of Internet-based continuing medical education. J Contin Educ Health Prof [Internet]. 2004 [cited 16 September 2015];2(1):20-30. Available from: http:// www.ncbi.nlm.nih.gov/pubmed/15069909

20. Cook D, Levinson A, Garside S, Dupras D, Erwin $\mathrm{P}$, Montori $\mathrm{V}$. Internet-based learning in the health 
professions: a meta-analysis. JAMA [Internet]. 2008 [cited 16 September 2015];300(10):1181-96. Available from: http://www.ncbi.nlm.nih.gov/ pubmed/18780847

21. Cook D, Levinson A, Garside S. Time and learning efficiency in Internet-based learning: a systematic review and meta-analysis. Adv Health Sci Educ Theory Pract [Internet]. 2010 [cited 16 September 2015];15(5):755-70. Available from: http://www. ncbi.nlm.nih.gov/pubmed/20467807

22. Cobb S. Internet continuing education for health care professionals: an integrative review. J Contin Educ Health Prof [Internet]. 2004 [cited 16 September 2015];24(3):171-80. Available from: http://www. ncbi.nlm.nih.gov/pubmed/15490549
23. Majalah Kedokteran Indonesia. Berita MKI [Internet]. Majalah Kedokteran Indonesia. [cited 21 September 2015]. Available from: http://mki. idionline.org/

24. IDI Online. Informasi CME Online [Internet]. 2010 [cited 21 September 2015]. Available from: http:// www.idicmeonline.org/ InformasiCME/tabid/62/ Default.aspx

25. CME Medicinus Online. Informasi [Internet]. CME Medicinus Online. [cited 17 September 2015]. Available from: http://cme.medicinus.co/files/pdf/ info/info_cme.pdf

26. Kalbe. Continuing Medical Education [Internet]. Kalbe. [cited 18 September 2015]. Available from: http://www.kalbemed.com/CME.aspx 